\title{
Determinants of Foreign Portfolio Inflows: Analysis and Implications for China
}

\author{
Fayyaz Ahmad \\ School of Economics, Lanzhou University \\ Lanzhou, Gansu Province, China \\ Dr. Muhammad Umar Draz \\ Department of Management and Humanities \\ Universiti Teknologi PETRONAS \\ 32610 Seri Iskandar, Tronoh, Perak Darul Ridzuan, Malaysia \\ Tel: 60-5-368-7732Ｅ-mail: umardraz2626@gmail.com \\ Su-chang Yang \\ School of Economics, Lanzhou University \\ Lanzhou, Gansu Province, China
}

Received: August 16, 2015 Accepted: Sep. 23, 2015 Published: December 1, 2015

doi:10.5296/ajfa.v7i2.8165 URL: http://dx.doi.org/10.5296/ajfa.v7i2.8165

\begin{abstract}
In emerging markets, a number of factors like GDP growth, market efficiency and higher earnings expectations play a vital role in attracting stable and smooth foreign investment. This work is intended to explore the determinants of FPI in China and compare the results with determinants of FPI in India explored by Garg and Dua (2014). We have applied multiple-regression model for ten years' data ranging from 2001 to 2010. The results indicate that external debts are the most significant determinant of FPI for China. We concur with Garg and Dua (2014) that GDP growth, FDI and exchange rate are among the significant determinants of FPI. Our findings suggest that China needs to sustain its economic growth in order to attract more FPI.
\end{abstract}

Keywords: China, FPI, GDP, India 


\section{Introduction}

Growth of capital flows to emerging world since the end of the $20^{\text {th }}$ century stimulated a hot debate among the scholars. Generally, this shift is attributed to change in different economic, fundamental and country specific conditions round the globe. Our interest here centers upon the study of different factors which are responsible in driving short term capital flows to China and India, focusing of FPI inflows of both countries. Foreign capital flows play an important role in the economy. These flows bridge the investment gap and fulfill the capital needs of a country at the domestic and international level. In the present era of globalization and financial liberalization, foreign investors from various countries of the world are willing to invest in the rest of the world. Recently, Foreign Portfolio investment (FPI) is becoming a common form of investment in many countries of the world. Portfolio investors, as compared to FDI investors, invest for a short term period and their purpose is to speculate the market boom.

Investment in foreign countries is a source of earning as well as helpful to diversify the portfolio risk of the investors. Since last decade, trend to invest in a foreign country is encouraging among foreign investors as mentioned by Daly \& Xuan (2013) in their research that, still most of the investors like to invest in their domestic market. This phenomenon is known as investor home-bias. So, to attract a handsome amount of investment, the host country needs to provide an attractive package to the investors. Fewer restrictions on capital flows, an attractive opportunity for investment and with the splendid growth rate of the economy, the emerging markets are the best place to invest from the last two decades.

Investors around the globe are interested to invest in financial markets of China and India because of their economic growth rates. Foreign capital inflows started in India in 1991, while China received its first FPI in 1997. Since the last decade, both countries experienced higher growth in FPI. China's FPI growth is significantly higher than India on average, but both countries are growing with an increasing trend. Global financial crises slowed down many economies of the world and FPI in China and India had a significant downfall in 2008.

This work is intended to explore the determinants of FPI in China and compare the results with determinants of FPI in India explored by Garg and Dua (2014). After an introduction and background, the next section encompasses the review of available literature on determinants of FPI. Section 3 provides the description of the variables employed while section 4 describes the data, methodology and empirical analysis. Section 5, represents the results and discussions. Finally, section 6 consists of concluding remarks and suggestions for policy makers.

\section{Literature review}

Cross border equity flows are very imperative in current days and geographical components are very crucial in international capital flows. International capital markets are not frictionless and are segmented by information asymmetries. Gross transaction flows depend on market size and the information cost, in source and as well as, in destination countries. IMF survey dataset of cross border equity holdings established that market size, transaction cost and 
information asymmetries are the major determinants of cross border portfolio selections. The importance of the drivers of portfolio capital flows fluctuates in countless time segments. Key changes ensue in the importance of portfolio driving factors with the crucial market events or shocks. Investors pay more attention to regional development of emerging markets when market tensions are elevated, but extreme tensions create panic and investors move their funds. At such times, market development plays only a marginal role (Faruqee, Li, \& Yan, 2004; Portes \& Rey, 2005; Duca, 2012)

Previous studies about determinants of international capital flows can be categorized into three concepts; home bias of investors, developed nations and emerging markets. Each category has its specific elements which attract foreign capital to that region. One motivation behind foreign investment is, to diversify the investment risk of a portfolio investment. Ancillary this, the source country investors with a higher level of home bias, prefers to invest towards those countries, which offer them better diversification opportunities. In different parts of the world, masses still prefer to invest in their own domestic markets and thus undervalue the diversification benefits. Both developing and advanced nations have this trend; the Australian investors invest a significant percentage of their portfolio in domestic market. Trade, governance, market size, cross border capital controls and low transaction cost are ominously influential to lessen home bias of Australian investors, and urge them to invest in international markets (Coeurdacier \& Guibaud, 2011; Daly \& Xuan, 2013).

The strongest determinant of capital flows to the USA is the financial development of the country. The countries with less develop financial markets invest a large portion of their portfolio in US markets. The countries that trade more with US, and have fewer capital controls in their countries invest more in debt and equity market in the United States. Internal country- specific factors may influence foreign portfolio inflows. Institutions and domestic risk of a country play an essential role to determine capital flows both in the shape of FDI and FPI. In South Africa, secure property rights and low domestic risk affect positively to the absolute volume of short term and long term capital flows (Egly, Johnk, \& Liston, 2010; Forbes, 2010; Gwenhamo \& Fedderke, 2013).

Before the financial crisis of 2008, FPI shifted from advanced to developing nations. FPI flows have strong positive and a long term relationship with market capitalization and the degree of openness in Nigeria. The neighboring countries also have a positive or negative impact on capital flows to a particular host country. The safety of funds is very important consideration among the investors. The level of the expected rate of return from any portfolio is associated with the level of political risk in that country. Investors prefer to shift their funds from politically less stable to more stable countries. Cultural characteristics of originating and destination countries are also important determinants of FPI flows (Chukwuemeka, Stella, Oduh, \& Onyema, 2012; Smimou, 2014).

Emerging markets like India received massive amounts of foreign investment during past two decades. The determinants of foreign institutional investment (FII) in India are exchange rate, domestic inflation, returns of domestic equity market and risk and return associated with US equity market. While, the foremost determinants of portfolio inflows are lower exchange rate 
and greater diversification opportunities. Higher equity returns of other emerging economies are depressing these flows. Domestic stock market performance, exchange rate and domestic output growth are also important determinants of FPI in India. Determinants of capital flows in the Asian and Latin American markets are GDP, interest rate, trade openness and financial interrelations. Tax incentive and higher interest rates or dividend rates are an attractive tool to increase cross-border investment. Low taxes on interest or dividend received by investors, associated with huge inflows of foreign capital to APEC region, and thus, help to strengthen their competitive position among other countries (Lee, Huh, \& Kim, 2012; P. Srinivasan \& M. Kalaivani 2013; (Yang, Xiong, \& Ze, 2013; Garg \& Dua, 2014).

Equity market characteristics of host countries are pivotal in the decision making process of allocation of funds, in a country. Whereas investing abroad, foreign portfolio equity investors keep in view numerous factors like, size, trading cost and market liquidity. Foreign portfolio investors prefer to invest more in larger, more liquid and more efficient markets, with low trading cost. The population ageing, money, institution and deviation from uncovered interest parity (UIP) are also the dominant factors in the development of capital flows. Portfolio inflows are negatively correlated with low quality of institutions. Cultural distance is also considerable; common language and religion among the countries, trading with each other, have a positive effect on the FPI holdings of both debt and equity. These effects are greater for the cross-border equity than debt. Factors that influence the debt or equity flows at international level are important for researchers as well as policy makers; investor protection is one of these factors. Investors tend to invest in those countries where better investors' protection procedures are practiced. Generally, countries which follow the Common English Law seem to attract the highest amount of foreign portfolio equity. Especially in case of foreign investment, the investor protection regulations are important to attract FPI in the country. (De Santis \& Lührmann, 2009; Poshakwale \& Thapa, 2011; Aggarwal, Kearney, \& Lucey, 2012; Thapa \& Poshakwale, 2012).

After a large scale privatization in 1997 and 1998, all state owned enterprises, except a few monopolies, were liquidated and sold to private investors. In the late $90 \mathrm{~s}$, China became an open economy that led to a massive foreign capital inflows starting from 1997. During 2001-2004, the state owned enterprises reduced by 48\%. Meanwhile, Chinese government reduced tariffs, trade barriers, modified the regulations and joined the World Trade Organization (WTO) (Shen, 2006). On the other hand, India adopted socialist policies after its independence in 1947. Attempts to liberalize economic policies in different time spans went in vain. At first, the government attempted to open the economy in 1966 but it was reversed in the next year. Prime Minister Rajiv Gandhi made the second major contribution in 1985; although this process stopped in 1987 but was not reversed. Later in 1991, the President and a technical team of intellectuals supported the finance minister Manmohan Singh for economic reforms. Though political pressure was there, but the Indian government was ready to take necessary steps for reforms (Mukherji, 2009).

As a result of the balance of payment crisis in 1991, India had to pledge 20 tons of gold to Union Bank of Switzerland and 47 tons to Bank of England to make a deal with the IMF (Weinraub, 1991). The IMF imposed various conditions and demand for economic reforms 
against the loan. In June 1991, following the general elections, the new government came to power inheriting one of the most complex trade regimes in Indian history. The newly established government, as stated by Krishna \& Mitra (1998), had to sort out the problem of severe restrictions on import export and extraordinary tariff on imports. Later in July 1991, government announced liberal trade policy that resulted in removal of most of the licensing requirements, reductions in import tariff and other non- tariff restrictions on trade. Consequently, FPI investors started investing in the Indian market for the first time in 1991. At present, India is the world's second fastest growing economy just after China.

As Garg \& Dua (2014) mentioned that, the portfolio equity flows to developing countries are increased five times from fourteen billion dollars to sixty seven billion dollars during the period of five years. This amount reached to 128 billion dollars in 2010. Among all developing countries, the prominent recipients are China, India, Russia, Brazil and South Africa. China, India and Brazil receive seventy percent of total portfolio investment invested in developing countries. China had made tremendous progress for the last thirty years. At present, it's the second largest economy in the world after America. The Chinese economic reforms called "Socialism with Chinese characteristics" started in 1978 under the chairmanship of Premier Deng Xiaoping. The private sector of China grew remarkably, and the period of 1978- 2005 accounted for as much as 70\% of China's GDP. At first, the reforms started with agriculture sector and then slowly for the whole economic system.

In emerging markets, a number of factors like GDP growth, market efficiency and higher earnings expectations play a vital role in attracting stable and smooth foreign investment. In general, all these pull -factors on macro-economic level, with the help of FPI, prove to be crucial to finance the deficit of current account of host country. On the other hand, because of its volatile nature and reversal effect on economy, these flows are blamed for Mexican and East Asian crisis. As Duca (2012) referred that, in normal circumstances FPI flows are beneficial, but at the same time cause economic instability in time of crisis.

The literature on determinants of capital flows can be summarized into two main sets, internal or endogenous factors, and external or exogenous factors. Advanced countries attract ample amount of capital because of their economic growth and stable financial system. While, interest rate, exchange rate, diversification opportunity, earning expectations, low taxes and changes in developed markets, are the factors mainly focused for developing countries.

\subsection{Research Gap}

Most of the literature addressed the topic by taking sample of countries including developing and developed nations. Although, previous studies fairly contributed to enhance the understanding about the factors contributing towards growth of capital flows, but Asian countries, especially China, demand special focus. So it will be valuable to conduct a focused study for China.

\subsection{Contribution of the Paper}

This paper contributes to the current literature by studying the determinants of FPI in China and conducting a comparative study of China and India. 


\section{Methodology and results}

\subsection{Data and Variables}

Data used in our analysis is taken from World Bank site for last decade, for FDI, GDP, population growth and EXD. Data of FPI is taken from IMF. FPI consists of total portfolio investment flows. The data of all variables is taken on annual bases and the currency unit is USD. Also, some control variables are also discussed in earlier section to make this study comprehensive, which may influence FPI and considered in literature. The final sample for analysis consists of balanced panel of five variables, for the period from 2001 to 2010. Our core variables used are largely adopted from literature to make comprehensive comparison of our findings with previous work. Variables are abbreviated as follows:
FPI = Foreign Portfolio Investment
\{Dependent Variable\}
FDI $=$ Foreign Direct Investment
\{Independent Variable\}
GDP $=$ Gross Domestic Product
\{Independent Variable\}
$\mathrm{EXR}=$ Exchange Rate
\{Independent Variable\}
$\mathrm{EXD}=$ External Debts
\{Independent Variable\}
$\mathrm{P}=$ Population Growth
\{Independent Variable\}

The following Hypotheses are developed in light of theoretical discussion in the previous section, and will be used to certify the role of above mentioned variables and FPI:

$\mathrm{H}_{0}=\mathrm{FDI} / \mathrm{GDP} / \mathrm{EXR} / \mathrm{P} / \mathrm{EXD}$ is not significant in determining the FPI inflows in China $\mathrm{H}_{1}=\mathrm{FDI} / \mathrm{GDP} / \mathrm{EXR} / \mathrm{P} / \mathrm{EXD}$ is significant in determining the FPI inflows in China

\subsection{Statistical Analyses}

The analyses of our study are different from the existing literature. This paper is the only work that focuses on the determinants of FPI in China and finding out the most significant determinant. FPI of China has been taken as dependent variable, while FDI, GDP, EXR, EXD and population growth are used as independent variables. Since FPI is function of all these variables, we can easily develop this into mathematical form.

$$
\begin{gathered}
F P I_{t}=f_{1}\left(u_{t}^{f d i}, u_{t}^{g d p}, u_{t}^{e x r}, u_{t}^{e x d}, u_{t}^{p}\right) \\
F P I_{t}=f_{2}\left(u_{t}^{f d i}, u_{t}^{g d p}, u_{t}^{e x d}, u_{t}^{e x r}, u_{t}^{i t r}, u_{t}^{p}, u_{t}^{i f n}\right)
\end{gathered}
$$

Equation (1) indicates variable of interest which includes; foreign direct investment, $u_{t}^{f d i}$, gross domestic product, $u_{t}^{g d p}$, population growth, $u_{t}^{p}$, exchange rate, $u_{t}^{e x r}$,and external debts, $u_{t}^{\text {exd }}$. Frequently used variables in the existing literature include inflation and interest rate 


\section{Macrothink}

(Garg \& Dua, 2014; Yang, Xiong, \& Ze, 2013; Thapa \& Poshakwale, 2012). Equation (2) explains that FPI is a function of main and control variables, which include interest $\operatorname{rate} u_{t}^{i t r}$,

and inflation $u_{t}^{i f n}$

Regression model will be used to determine the relationship among above mentioned variables. Regression Model has two types: the first is Simple regression and the second one is Multiple Regression. The difference between two types is the number of Independent variables, the former has only one Independent Variable and the latter has more than one While, the Dependent Variable in both cases is only one. In our model, we are dealing with more than one independent variable, hence linear regression or correlation analysis cannot provide satisfactory results because of their limitations. Multiple Regressions is the Statistical tool, which is generally employed to examine the relationship between dependent and multiple independent variables.

$$
Y=a+b_{1} X_{1}+b_{2} X_{2} \ldots \ldots \ldots \ldots \ldots+b_{n} X_{n}
$$

Equation (3) indicates that, to predict variable $\mathrm{Y}$ we can use multiple independent variables; let's say from $X_{1}$ to $X_{n}$. After adjusting our variables into above equation, mathematical representation of our final model is presented in equation (4).

$$
Y=a+b_{1} f d i_{1}+b_{2} g d p_{2}+b_{3} \operatorname{exd}_{3}+b_{4} p_{4}+b_{5} \operatorname{exr}_{5}
$$

\section{Findings and Discussion}

This section represents the empirical analyses and discusses implication of findings. Table 1 represents the statistics summery of dependent and explanatory variables for sample period. In most cases, skewness $>0$ which indicates distribution is right skewed.

Table 1. Summary Statistics

\begin{tabular}{lcccccc}
\hline & EXR & EXD & GDP & FPI & FDI & P \\
Mean & 7.74 & 3.18 & 10.49 & 2.20 & 1.25 & 0.57 \\
Median & 8.08 & 3.03 & 10.05 & 1.91 & 1.22 & 0.57 \\
Std. Dev. & 0.65 & 1.22 & 1.77 & 1.87 & 7.57 & 0.07 \\
Skewness & -0.62 & 0.61 & 0.91 & 0.30 & 0.55 & 0.56 \\
Kurtosis & 1.60 & 2.42 & 2.89 & 1.47 & 2.35 & 2.27 \\
Jarque-Bera & 1.44 & 0.76 & 1.40 & 1.12 & 0.68 & 0.75 \\
Probability & 0.48 & 0.68 & 0.49 & 0.56 & 0.70 & 0.68 \\
\hline
\end{tabular}

Source: Authors' analyses in Eviews 
Kurtosis $<3$ shows that, distribution is flatter than normal with wider peak, which termed as Platykurtic distribution. While, values of Jarque-Bera test are also not very high; particularly for FDI, P, and EXD. The concept of stationary and non-stationary is important. A stationary series has a constant mean, variance and auto-covariance for each given lag. The results of a stationary series are reliable than non-stationary. Augmented Dickey-Fuller (ADF) using Schwaz criterion and Phillips Perron (PP) test is used for evaluation of a series as unit root test and results are presented in Table 2.

Table 2. Unit Root Test

\begin{tabular}{lllll}
\hline & \multicolumn{2}{l}{ Augmented Dickey-Fuller (ADF) } & Phillips-Perron (PP) \\
Variables & $\begin{array}{l}\text { ADF test } \\
\text { statistic }\end{array}$ & Critical value & PP test statistic & Critical value \\
& -2.21 & -1.98 & -2.79 & \\
EXR & -3.06 & -2.00 & -2.76 & -2.00 \\
FDI & -2.39 & -1.99 & -4.53 & -2.56 \\
EXD & -2.67 & -1.99 & -4.66 & -3.40 \\
GDP & -3.73 & -3.32 & -6.61 & -3.32 \\
FPI & -3.67 & -3.25 & -7.86 & -3.25 \\
P & & &
\end{tabular}

Source: Authors' analyses in Eviews

The computed ADF and PP test statistics values are smaller than critical values for all variables, at 5\% level of significance. The results support that all variables are stationary and reliable for regression results. Prior to estimating the regression model, variables are also tested for multicollinearity. The results are presented in Table 3, which indicates that most of cross correlation terms are fairly small for independent variables. So, there is no cause of concern about multicollinearity problem among variables.

Table 3. Correlation Matrix

\begin{tabular}{llllll}
\hline & EXD & EXR & FDI & GDP & P \\
EXD & 1 & & & & \\
EXR & -0.59 & 1 & & & \\
FDI & 0.69 & -0.83 & 1 & & \\
GDP & 0.37 & 0.002 & 0.48 & 1 & 1 \\
P & -0.39 & 0.79 & -0.83 & 0.0099 & 1 \\
\hline
\end{tabular}

Source: Authors' analyses in Eviews

Regression results are presented in Table 4, probability values for all variables are significant at the level of 5\%, which indicates the strong relationship among FPI and independent variables. Significant relationship exists between GDP and FPI which indicates that GDP is the strong determinant of FPI. Substantial relation with strong probability of FDI, P, EXR and EXD elaborate that all these variables strongly influence FPI level in China. 
Table 4. Ordinary Least Square Regression Results

\begin{tabular}{|c|c|c|c|}
\hline Variables & Coefficients & t-statistics & Probabilities \\
\hline $\mathrm{C}$ & 5.53 & 2.80 & 0.048 \\
\hline EXD & 2.06 & 9.53 & 0.0007 \\
\hline EXR & -2.74 & -9.86 & 0.0006 \\
\hline FDI & -2.50 & -7.46 & 0.0017 \\
\hline GDP & 6.90 & 13.37 & 0.0002 \\
\hline $\mathrm{P}$ & 1.24 & 6.60 & 0.0027 \\
\hline 0.99 & 1.36 & 2.55 & \\
\hline
\end{tabular}

Source: Authors' analyses in Eviews

While, R-squared value is higher than 0.9 and Durbin Watson 2.55 with F-statistics of 340, which demonstrates that variables applied in analysis are fairly uncorrelated.

Table 5. Complementary Test

\begin{tabular}{lll}
\hline Tests & F-statistics & Probabilities** \\
LM & 0.56 & $(0.63)^{* * *}$ \\
WH $^{*}$ & 1.75 & $(0.25)$ \\
ARCH & 5.56 & $(0.99)$ \\
RESET & 0.52 & $(0.49)$ \\
\hline
\end{tabular}

Source: Authors' analyses in Eviews

*WH is white Heteroscedasticity Test

**Level of significance is 5 per cent

$* * *$ Values in parenthesis are p-values

Furthermore, a series of specification tests is performed as cross check of results. The test battery includes test for serial correlation, LM test, White Heteroscedasticity test, RESET and ARCH test to check ARCH effect. Results are presented in Table 5, which indicates that in all cases corresponding values rejected the presence of autocorrelation in models. In addition, CUSUM test results presented in Figure 1; do not indicate any instability in model. 


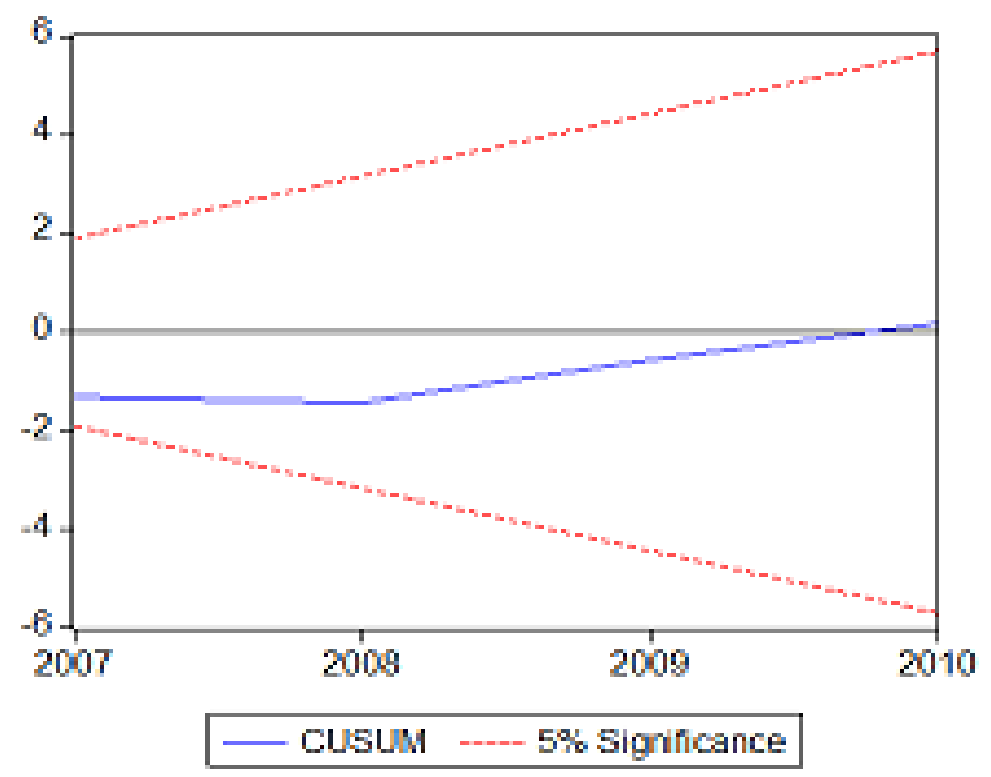

Figure 1. CUSUM Test for Stability Analysis, level of significance is 5\%.

The aforementioned empirical results show that, independent variables taken in our analysis are highly influential on FPI of china. Relationship between EXD and FPI is the most significant, which indicates that productive use of foreign loans is helpful to bring FPI flow in country. Progressive loans give hand to improve social and economic infrastructure, which automatically results in better performance of various sectors of economy. Relationship between GDP and FPI is obvious. Since last decade, growth rates of China are approximately in double figures, which give an indication of smooth working of economy. Comparatively few downfalls in economy and impressive growth rates attract foreign investors.

Exchange Rate reflects a significant relationship with FPI. Exchange rate appreciation indicates speculative opportunities for investors and with more investor's rights and high earning expectations, international community fell safe and confident to invest. Which leads to efficiency, transparency better infrastructure and improved investor's rights of stock exchange in country, hence enhance economic growth. Higher GDP growth and stable economic and political conditions urge foreign invests to invest long term funds in country, which specifies that chances of collapse are comparatively less. This situation increases investor's confidence about safety of funds, and they diversify their portfolio in form of FPI, to earn more and minimize risk associated with investment.

\section{Conclusion}

We concur with the existing literature that determinants vary from country to country and generally include economic growth, interest rate differential, currency exchange rate, country's political stability and capital control policy. In this paper, we investigated different factors which influence the FPI in China. Based on Regression Model for previous decade, we found that GDP, exchange rate, population growth, foreign direct Investment and external 
debts significant determinants of FPI in China. These findings are similar to what Garg \& Dua (2014) found in case of India. We further confirm that external debts are the most significant determinant of FPI in China.

Our findings suggest that China should pay attention to sustain its economic growth because its economic growth rate is already in double digits and comparatively higher than the Indian economy. Furthermore, reviewing its financial policies, especially the investors' rights and financial openness, is highly crucial for China to attract more foreign capital from the international community. Improved investors' rights will provide support during economic turmoil to resist against these disasters.

\section{Acknowledgement}

The authors are thankful to Professor Dr. Jason Zezhong Xiao (Cardiff University, UK) and Assistant Professor Dr. Ananda Jeeva (UCSI University, Malaysia) for their valuable suggestions and comments.

\section{References}

Aggarwal, R., Kearney, C., \& Lucey, B. (2012). Gravity and Culture in Foreign Portfolio Investment. Journal of Banking \& Finance, 525-538. http://dx.doi.org/10.1016/j.jbankfin.2011.08.007

Chukwuemeka, E. P., Stella, E. C., Oduh, V., \& Onyema, M. (2012). Modelling the Long Run Determinants of Foreign Portfolio Investment in Nigeria. Journal of Economics and Sustainable Development, 194-205

Coeurdacier, N., \& Guibaud, S. (2011). International Portfolio Diversification is Better Than You Think. Journal of International Money and Finance, 289-308. http://dx.doi.org/doi:10.1016/j.jimonfin.2010.10.003

Daly, K., \& Xuan, V. V. (2013). The determinants of home bias puzzle in equity portfolio investment in Australia. International Review of Financial Analysis, 34-42. http://dx.doi.org/10.1016/j.irfa.2012.05.005

De Santis, R. A., \& Lu“hrmann, M. (2009). On the Determinants of net International Portfolio Flows: A Global Perspective. Journal of International Money and Finance, 880-901. http://dx.doi.org/ 10.1016/j.jimonfin.2008.09.002

Duca, M. L. (2012). Modeling the time varying determinants of portfolio flows to emerging markets. Frankfurt am Main: European Central Bank.

Egly, P. V., Johnk, D. W., \& Liston, D. P. (2010). Foreign Portfolio Investment Inflows to The United States: The Impact of Risk Aversion And US Stock Market Performance. North American Journal of Finance and Banking Research, 25-41.

Faruqee, H., Li, S., \& Yan, I. K. (2004). The Determinants of International Portfolio Holdings and Home Bias. Washington, DC: International Monetary Fund. 
Forbes, K. J. (2010). Why do Foreigners Invest in The United States? Journal of International Economics, 3-21. http://dx.doi.org/ 10.1016/j.jinteco.2009.09.001

Garg, R., \& Dua, P. (2014). Foreign Portfolio Investment Flows to India:. World Development, 16-28. http://dx.doi.org/10.1016/j.worlddev.2014.01.030

Gwenhamo, F., \& Fedderke, o. W. (2013). The Composition of Foreign Capital Stocks in South Africa: The Role of Institutions, Domestic Risk and Neighbourhood Effects. Economic Modelling, 763-770. http://dx.doi.org/10.1016/j.econmod.2013.09.001

Krishna, P., \& Mitra, D. (1998). Trade Liberalization, Market Discipline and Productivity Growth: New Evidence From India. Journal of Development Economics, 447-462.

Lee, H. H., Huh, H. S., \& Kim, W. J. (2012). Cross-Border Portfolio Investment in The APEC Region. Japan and the World Economy, 44-56. http://dx.doi.org/ 10.1016/j.japwor.2011.11.002

Mukherji, R. (2009). The State, Economic Growth,and Development in India. India Review, 81-106. http://dx.doi.org/ 10.1080/14736480802665238

Portes, R., \& Rey, H. (2005). The Determinants of Cross-Border Equity Flows. Journal of International Economics, 269- 296. . http://dx.doi.org/doi:10.1016/j.jinteco.2004.05.002

Poshakwale, S. S., \& Thapa, C. (2011). Investor Protection and International Equity Portfolio Investments. Global Finance Journal, 116-129. http://dx.doi.org/ 10.1016/j.gfj.2011.10.003

Shen, H. M. (2006, 09 23). Private Sector Development Projects. Retrieved June Thursday, 2014, from Wikipedia: http://8km.de/2006/19

Smimou, K. (2014). International Portfolio Choice and Political Instability Risk: A Multi-Objective Approach. European Journal of Operational Research, 546-560. http://dx.doi.org/10.1016/j.ejor.2013.01.024

Stanton, J. M. (2001). History of Linear Regression for Statistics Instructors Instructors. Journal of Statistics Education, 1-16.

Thapa, C., \& Poshakwale, S. S. (2012). Country-Specific Equity Market Characteristics and Foreign Equity Portfolio Allocation. Journal of International Money and Finance, 189-211. . http://dx.doi.org/10.1016/j.jimonfin.2011.10.011

Weinraub, B. (1991, o6 29). Economic Crisis Forcing Once Self-Reliant India to Seek Aid. Retrieved 06 Thursday, 2014, from The New York Times: http://www.nytimes.com/1991/06/29/world/economic-crisis-forcing-once-self-reliant-india-to -seek-aid.html

Yang, H., Xiong, Y., \& Ze, Y. (2013). A Comparative Study of Determinants of International Capital Flows to Asian and Latin American Emerging Countries. Procedia Computer Science, 1258 - 1265. http://dx.doi.org/ 10.1016/j.procs.2013.05.160 